\title{
PRESIDENT'S REPORT AND REPORTS OF THE COM- MITTEES OF THE INSTITUTE AND THE COM- MITTEES OF ITS BOARD OF MANAGERS
}

\author{
FOR THE FISCAL YEAR ENDING SEPTEMBER 30, 1914.
}

\section{To the Members of The Franklin Institute:}

Your Board of Managers, in addition to inviting a close study of the reports of the several committees covering the activities of the Institute during the year ending September 30, I914, and presented herewith, earnestly call your attention to several matters of the first importance to the Institute, and to that progress in mechanic arts which it is the Institute's function to promote.

Previous reports of the Board have kept you concurrently familiar with the continuing satisfactory progress of the general work of the Institute. Our membership has recently been greatly enlarged; the attendance at our lectures frequently taxes the seating capacity of our Hall; through the JOURNAL OF THE INSTITUTE our membership and the scientific world generally are promptly and authoritatively informed of the results of the latest researches in physical science and the most recent achievements of the engineering professions; the year's additions to the Library are more than usual; the work of our Science and Arts Committee has, as always, been marked by devotion and efficiency; the usefulness of our School of Mechanic Arts, notable for nearly ninety years, has never been greater than at present. These facts, while offering gratifying proof of the continuing usefulness of our Institute, should not satisfy us, in view of the opportunities for greater service which, as we believe, the near future offers.

As you are aware, the Institute owns a site upon the Parkway, perfectly located, and entirely sufficient for such new building or buildings as will best serve to enable it to meet these opportunities. Four years ago the Institute's income would not have been sufficient to maintain a modern adequate structure and to carry on therein, in the fullest degree, the work formulated in its charter. After this year, however, in the event of the friends of the Institute meeting the conditions of the Wahl bequest, the Institute will possess such an annual income as would justify it in so occupying a modern building as to greatly increase the extent and value of its services in the special field of its efforts. This building. on the south side of Logan Square, at the corner of Nineteenth and Race Streets, when erected, will have for its neighbors, as you know, the Cathedral, the Wills Hospital, the Academy of Natural Sciences, and the great and noble new Public Library. The building thus worthily located will face Logan Square and have a frontage of $\mathrm{I}$ Io feet and a depth of Izo feet. The entrance will be on Race Street, and the façade, while simple, will be dignified and in keeping with the purposes of the structure and with its location. The ground floor will be devoted mainly to laboratories, notably a thoroughly-equipped testing laboratory for the use of the Committee on Science and the Arts. On the first floor will be located the main Lecture Hall, fitted with every modern appliance for lecture demonstration and experiment, with a large members" 
room, apparatus and model rooms, offices and preparation rooms. The second floor will contain well-equipped lecture rooms for the use of such scientific and technical societies as may wish to use them, together with a number of office rooms and a Board room. The third floor will be occupied by the School, and the fourth floor will be devoted entirely to the Library.

We have only about one-third of the money necessary for such a building as we desire to erect; we own, however, what we believe to be the building site best located for the purposes of the Institute, and we believe that our annual income within a year or two will warrant the Institute in occupying such a building should the funds necessary for its erection be obtained. We therefore particularly urge, first, that the members and friends of the Institute see to it that the conditions of the Wahl bequest be promptly met: and, second, that the necessary money for the completion of the building fund, approximately half a million dollars, be obtained through private contribution or public grant: all this, that the work of the Institute may result in increased benefit to the citizen and to the State.

Recalling that the Institute's success in its efforts to promote the mechanic arts depends upon the degree of intelligence and devotion exercised in the committee rooms and in the office of the Secretary, your attention is again invited to the Board's and Institute's Committee reports and to our latest Year Book, as evidence adequate, though not comprehensive, of the ability of our Institute to-day to call to its service devotion and intelligence of the highest order.

Respectfully submitted, FOR THE BOARD OF MANAGERS,

Walton ClakK, President.

Philadelphia, Jantiary 20, 1915.

\section{REPORT OF THE COMMITTEE ON LIBRARY} FOR THE FISCAL YEAR ENDING SEPTEMBER 30, 1914.

To the President and Hembers of The Franklin Institute:

During the year there were expended $\$ 910.26$ for the purchase of 306 volumes, I pamphlet, ancl 3 maps; $\$ 1575.92$ for subscriptions to periodicals; $\$ 750.35$ for binding 328 volumes; $\$ 4267.86$ for salaries and expenses. There were available for meeting these expenditures $\$ 6650$, appropriated by the Board of Managers, and $\$ 2 ; \mathrm{I} . \mathrm{IO}$, being the income from the several Library funds.

The accessions by gift, exchange, and from the Jocrnal totalled irga volumes, 955 pamphlets, 3 maps, and I drawing.

The additions inclucle many valuable works. More books have been purchased than in the previous year, and the falling off in the total additions is due only to a decrease in the accessions of pamphlets. Much valuable 